\title{
University teachers' perception of barriers to the use of digital technologies: the importance of the academic discipline
}

\author{
Cristina Mercader ${ }^{*}$ (D) and Joaquín Gairín
}

\author{
* Correspondence: Cristina \\ mercader@uab.cat \\ Universitat Autònoma de Barcelona, \\ Plaça del Coneixement, Edifici \\ G6-245, 08193 Bellaterra, Barcelona, \\ Spain
}

\begin{abstract}
Digital technologies are currently one of the most used resources among students for developing their personalized learning environment. However, recent studies continue to demonstrate a lack of usage on the part of teaching staff for developing their teaching practices, especially at the university level. Through the identification of personal, professional, institutional, and contextual barriers, this study seeks to reveal the reasons why teachers in institutions of higher education do not use digital technologies for teaching purposes and whether the academic discipline influences this perception. The results suggest that professional barriers are the most prevalent and that the discipline of arts and humanities is where the most obstacles are perceived. In conclusion, there is a need for better professional development for teachers and more institutional involvement through strategic plans.
\end{abstract}

Keywords: Barriers, Digital technologies, Teaching, University, Disciplines

\section{Introduction}

Digital Technologies are a set of all kinds of hardware and software devices that facilitate communication and access, transmission and storage of information and knowledge in a digital environment. The Horizon Report (Johnson et al., 2016) demonstrates the lack of digital technology integration in the classroom, especially in terms of emerging technologies such as: BYOD (bring your own device), learning analytics and adaptive learning, augmented and virtual reality, and robotics. When analysing the use of the Internet in the teaching-learning process in universities, Duart (2011) confirms low usage by teachers (only 50\% use it for teaching) and it is more widespread use in research. Marcelo, Yot, and Mayor (2015), in accordance with Kedrova and Potemkin (2015), confirm this situation, pointing out that $44 \%$ of university teachers use digital technologies infrequently in their teaching practice and, on the few occasions that they are used, teachers tend to turn to the same type: technologies that can be used more for supporting their lecture sessions, and less so the development of student-centred activities.

Along the same lines, Mercader and Gairín's study (2017) analyses the tools used by university teachers, detecting that the only widespread ones are visual presentations and virtual platforms, which are used to support teachers' lecture sessions, thus relegating the tools that involve an active role on the part of students (social networks,

(c) The Author(s). 2020 Open Access This article is distributed under the terms of the Creative Commons Attribution 4.0 International License (http://creativecommons.org/licenses/by/4.0/), which permits unrestricted use, distribution, and reproduction in any medium, provided you give appropriate credit to the original author(s) and the source, provide a link to the Creative Commons license, and indicate if changes were made. 
blogs, augmented reality, etc.) to less important and sporadic use among teachers. Other research indicates that the use of digital technologies is more common for the prior preparation of classes or for the administrative classroom management, but not for didactic use (Berzosa \& Arroyo, 2016; Gumbau et al., 2016). The low use becomes more evident when we analyze general studies that focus on the use of digital technologies, which demonstrate a lack of integration among teachers in most cases (El Semary, 2011; Hernández-Ramos, Martínez-Abad, García, Herrera, \& Rodríguez-Conde, 2014; Teo, 2015; Venkatesh, 2000; Zempoalteca, Barragán, González, \& Guzmán, 2017), compared to the results in specific studies on the use of one particular tool.

The literature thus substantiates the notion that, in the academic world, digital technologies are not integrated into teaching practices, even though students do take advantage of their educational possibilities (Vázquez, 2015). If the majority of university teachers, regardless of academic discipline, recognize the potential digital technologies have for learning (Hue \& Jalil, 2013; Kurt, 2011), then why don't these same university teachers use diverse digital technologies in class more frequently?

\section{Barriers to the use of digital technologies in education}

Marcelo et al. (2015) and Pajo and Wallace (2001) push for analyzing the reasons why digital technologies are not used more extensively, especially among young teachers. The British Educational Communications and Technology Agency (BECTA, 2004), Kalembera and Majawa (2015), and Peansupap and Walker (2006) highlight the importance of recognizing the barriers that exist-in a given context-that affect the teaching staff and the organization, as a first and necessary step towards mitigating these barriers' impact or eliminating them completely and thus achieving full digital technology integration. From the point of view of teacher benefits, the identification and contemplation of existing obstacles can help teachers focus on developing the necessary and appropriate skills for their teaching practices, as well as familiarizing themselves with the facilitating factors and strategies that they can implement in order to eliminate the obstacles that are within their power (Ertmer, 1999).

EDUCAUSE (Johnson et al., 2016) notes that teachers use digital technologies in their personal lives, but that, when applied in classrooms, they encounter serious technical, logistical, and pedagogical problems. Accordingly, Cuhadar (2018) infers that the technological competency level of teachers is intermediate or lower. Sevillano (2015) associates the problems stemming from the integration of digital technologies at the personal level with their underutilization or with their mechanical and educationally pointless use.

At the institutional level, deficits are detected in the non-existence of a common, unified practice in centres of higher education. In general, there are no institutional plans or models for integrating digital technologies into the classroom (Chukwunonso \& Oguike, 2013; Duart, 2011; El Semary, 2011; Llorens et al., 2016; Mercader, 2019). It is therefore common for teachers to establish their own practices individually, meaning that the frequency and consistency of technology usage depends solely on the given teacher's interest, which leads to sporadic and inconsistent integration (Selwyn, 2007). The lack of a common approach on the part of the educational centre negatively impacts innovative teachers because they do not feel supported by their institution (Gumbau et al., 2016). 
Plans to incorporate technologies into trainings have focused their policies at the operational level and not at the strategic one (Valverde, Garrido, \& Sosa, 2010). Improvements are implemented in the allocation of equipment and in teacher training, but not in plans that tackle the different dimensions affected by the change, with policies that correspond to the detected needs. Along these lines, the UNIVERSITIC report (Gómez, 2017) detects a progressive decrease, over recent years, of institutions' commitment to training their teachers in digital technologies. The data indicates that only $20 \%$ of teaching and research staff have received training in digital technologies in the last year. Similarly, $72 \%$ of the institutions that participated in the study do not have a plan for allocating and distributing human resources linked to ICT. On the other hand, there is a recognized deficit in digital literacy among teachers-literacy in competencies that would help make digital technology integration neither random nor underutilized, but instead planned and suitable for meeting real educational needs (Chukwunonso \& Oguike, 2013; Marín, Vázquez, Llorente, \& Cabero, 2012; Salcines, González, \& Briones, 2017; Zempoalteca et al., 2017).

Some authors have suggested classifications for the typology of barriers or obstacles to the integration of digital technologies. The Bland (2007), British Educational Communications and Technology Agency (BECTA, 2004), and Magen-Nagar and Maskit (2016) all distinguish between individual or personal barriers and institutional or organizational ones. Individual barriers refer to traits specific to individual people, such as lack of time or lack of training; meanwhile, institutional barriers are associated with a responsibility pertaining to the organization itself, such as lack of benefits or resistance to change. Peansupap and Walker (2006) add the group into their classification system, defining three types of barriers: individual, organizational, and group; conversely, Buchanan, Sainter, and Saunders (2013) completely disregard the organization in their understanding that influencing factors can be classified as either individual or contextual.

Ertmer (1999) discerns between primary and secondary barriers to the integration of digital technologies. Primary barriers refer to external obstacles, which are not specific to the person, such as limited resources or lack of technical support. Secondary barriers are internal obstacles, such as lack of confidence or different mindsets. This differentiation also involves a different outlook, given how difficult it is for change to take place, seeing as secondary barriers are more deeply rooted. The author thus deems secondary barriers more complex and more difficult to dispose of.

The classification proposed by Schulz, Isabwe, and Reichert (2015) encompasses four areas: (1) human factors, such as mindset and confidence; (2) intrinsic values, such as level of interest or satisfaction; (3) the requirements of the tool itself, such as adaptation or learning processes; all of these factors are in turn influenced by (4) environmental factors. In turn, the contributions of Cabero (2005), Prendes (2010), Romero (2011), and Salinas (2008) point to the following types of factors: political (enabling university policies), economic (resources for change), ideological (teachers being able to see the advantages), training (professional learning capacity), cultural (culture of change, culture of intention) and psychological (trusting technology).

In Table 1 there is a summary of the information of the different typologies organized by the three wide types: personal/internal/individual barriers, organizational/institutional barriers, contextual/environmental barriers. 
Table 1 Summary of typologies of barriers for integrating DT

\begin{tabular}{llll}
\hline Authors & Individual / Personal & Institution / Organization & Systemic / Contextual \\
\hline Ertmer (1999) & $*$ & $*$ & $*$ \\
BECTA (2004) & $*$ & $*$ & $*$ \\
Bland (2007) & $*$ & $*$ & $*$ \\
Peansupap and Walker (2006) & $*$ & & $*$ \\
Buchanan et al. (2013) & $*$ & & $*$ \\
Magen-Nagar and Maskit (2016) & $*$ & & \\
Schulz, Isabwe \& Reichert (2015) & $*$ & &
\end{tabular}

Upon analysing the classifications and groupings formulated by the aforementioned authors, we propose the following typology, divided into four areas: personal, professional, institutional, and contextual. Therefore, our typology splits the internal barriers into personal and professional barriers: The first one is related to personal traits and the other one to professional aspects. We distinguish them because we include in personal barriers those related to people's characteristics such as attitudes towards DT, technophobia, lack of interest in DT, lack of confidence when using DT in their life, rejection to change ... While professional barriers refer to the people's professional characteristics. In this sense, it refers to obstacles that are linked to their profession -teaching-, such as lack of DT training, pedagogical conceptions of teaching with DT, lack of experience with DT in class, knowledge of the didactic use of DT, etc.

Within each of these areas we can find each of the barriers to technology integration in education that exist in the literature, combining them with, in addition, Robbins and Judge's (2013) and Tejada's (1998) proposed typology of resistance to change.

\section{Academic discipline as a factor for using digital technologies in class}

Some authors maintain that certain obstacles are felt more or less depending on the academic discipline with which the teacher is affiliated, given that technologies are used to a greater or lesser extent in different subject areas (Burkhardt, 1994; Quicios, 2015). Velasco (2011) considers the type of academic discipline to be indicative of the level of digital technology integration. Specifically, he points out that teachers of the humanities and social sciences do not use digital technologies as much as the rest of the scientific fields. Salcines et al. (2017) identify differences in digital usage between branches of knowledge: although the differences are not substantial, digital usage is more common in engineering and architecture and less so in the social sciences and the health sciences.

On the contrary, Al-Senaidi, Lin, and Poirot (2009) maintains that the academic discipline is not a factor that influences existing barriers in general unless a lack of equipment is taken into consideration. Shelton (2014) points out that the type of academic discipline is only related to some obstacles, especially when there is a lack of confidence-on the part of the teachers-in digital technologies. The studies analyzing the influence of the academic discipline in the integration of digital technologies or in the reluctance to implement them are not entirely conclusive: while some highlight a correlation, others reject its existence or diminish its influential power.

Therefore, a continued analysis on current barriers remains justified; it is also pertinent if we bear in mind how fast technology evolves and the increase in the use of digital 
technologies, which can decrease operational capacity (such as the reach of Wi-Fi in classrooms when teachers want to promote interactive exercises). Similarly, what used to be an obstacle might now cease to be so (such as the lack of computers for teachers as a work tool). We need a continuous diagnostic assessment that gives rise to proposals for concrete interventions for eliminating these barriers. This need becomes even more pronounced if we bear in mind that only $41.67 \%$ of institutions analyse their technology integration and put strategies into practice for its incorporation (Llorens et al., 2016). We need this type of assessment to detect especially-among other issues-deficiencies on the organizational level.

\section{Materials and methods}

The goal of this study was to identify the barriers that university teachers from different disciplines encounter when integrating Digital Technology (DT) into their classrooms.

The research questions were: 1) What barriers exist for the use of DT?; and 2) Is the type of academic discipline a factor that impacts the perception of barriers to the use of DT?

In order to answer these questions, and based on the analysis of the literature, we established two initial hypotheses:

H1: There is a sphere of intervention (personal, professional, institutional, and contextual) in which barriers are detected at greater intensity.

$\mathrm{H} 2$ : Barriers vary depending on the academic discipline of the university teaching staff.

Understanding that the reality is holistic (Lincoln \& Guba, 1985), the study is conducted under an interpretative paradigm. Regarding the method, the research develops a multiple case study. The study was carried out using quantitative methodology in four Spain universities: two publicly owned and two privately owned, with clearly different characteristics regarding size and location, with the purpose of avoiding as much as possible the influence these factors.

Although universities are organizations with special characteristics and different from one another (Shelton, 2014), the multiple case study allows to maintain the holistic and substantial characteristics of the reality studied (Yin, 1994).

The instrument employed was an ad hoc self-administrated web-based survey, whose content was validated by 12 theoretical and practical judges, and which had an internal consistency of .874 according to Cronbach's alpha. The questionnaire consisted of four sections: a) sociodemographic data (7 items); b) mastery and integration of DT (9 items); c) barriers to the use of DT (33 items) linked to four spheres (personal, professional, institutional, and contextual) and evaluated on a Likert scale; and d) open questions about the biggest barriers ( 3 items). Participants had to indicate, on a scale of 1 to 4 (with 1 being strongly disagree and 4 being strongly agree) whether they agree that the given barriers exist. Concerning ethical considerations, all participants received detailed information regarding the study conditions: purpose, researchers involved, confidentiality of data, anonymity, voluntary participation, and their right to withdraw at any time.

Participants were 527 university teachers from the 4 universities selected. First, we acquired the emails of all 1569 teachers working in the four universities. We send the 
survey to the 1503 teachers whose emails were available, and we received 731 answers but not all finished it or were valid. After that, we randomly chose the sample, ensuring that representation was upheld in terms of the universities and academic disciplines included. In order to preserve the reliability of the sample, the sample was calculated to have the maximum of $8 \%$ of error and $95 \%$ of accuracy. The final sample is composed by 527 university teachers: $19.9 \%$ from the field of science and technology; $21.1 \%$ from the arts and humanities; $30.4 \%$ from the health sciences; and $28.7 \%$ of social sciences. $51.4 \%$ of the sample were men, the average age was 46.15 years $(\mathrm{SD}=9.92)$ and the average teaching experience was 14.47 years $(S D=10.29)$. Regarding their position, 44.4\% do not have permanent positions (associate professors, predoctoral teachers, postdoctoral fellowships ...). Regarding Digital Technology skills, 64.9\% never have received training about ICT, $9.5 \%$ of them affirm that their digital skills are in the first level, $50.5 \%$ in the second level, $28.8 \%$ in the third level and $11.2 \%$ in the fourth and maximum level.

The analyses performed are both univariate and multivariate, using the IBM Statistical Package for the Social Sciences (SPSS v.20). The tests performed were descriptive (means and deviations) and inferential (ANOVA and Wilcoxon test).

\section{Results}

The results were divided into two sections, according to the research questions posed.

\section{Barriers to DT integration}

The results suggest that, in general, teachers perceive practically all the possible barriers. In fact, the mean ranking is below 2 for only two of the barriers: institutional rigidity $(\mathrm{M}=1.71, \mathrm{SD}=0.71)$ and pre-established practices $(\mathrm{M}=1.93, \mathrm{SD}=0.76)$. Some $94 \%$ of the barriers are identified by teachers as obstacles to integrating digital technologies.

Figure 1 shows the mean rankings per barrier. Using the obtained results as a reference, and organizing the rankings by quartile, we were able to ascertain that the highest rankings $(M>2.73)$ correspond with the following barriers: lack of training $(M=2.73$, $\mathrm{SD}=0.80)$; lack of knowledge of digital technology teaching approaches $(\mathrm{M}=2.74, \mathrm{SD}=$ $0.65)$; lack of planning $(\mathrm{M}=2.83, \mathrm{SD}=0.84)$; excessive workload $(\mathrm{M}=2.87, \mathrm{SD}=0.87)$; lack of time $(\mathrm{M}=3.05, \mathrm{SD}=0.79)$; generational gap $(\mathrm{M}=3.06, \mathrm{SD}=0.83)$; technophobia $(\mathrm{M}=3.10, \mathrm{SD}=0.81)$; lack of assessment $(\mathrm{M}=3.20, \mathrm{SD}=0.81)$; and lack of incentives $(\mathrm{M}=3.30, \mathrm{SD}=0.74)$.

The analyses of the open questions coincided with the ratings that the Likert scale gave. The most important barrier that teachers identified was lack of time $(N=82)$, followed by lack of training $(N=34)$, lack of infrastructure $(N=33)$, lack of knowledge of digital technology teaching approaches $(N=28)$, excessive workload $(N=26)$, generational gap $(N=24)$, and quality of infrastructure $(N=21)$.

The barriers most highlighted by teachers reach across all four spheres: the personal, professional, institutional, and contextual. The barriers with the highest rankings are, without a doubt, mainly professional and institutional, but these two fields are also the ones with the most subtypes of barriers within their area. Due to this fact, and in order to corroborate $\mathrm{H} 1$, the means are calculated by dimensions (see Table 2) and then compared. 


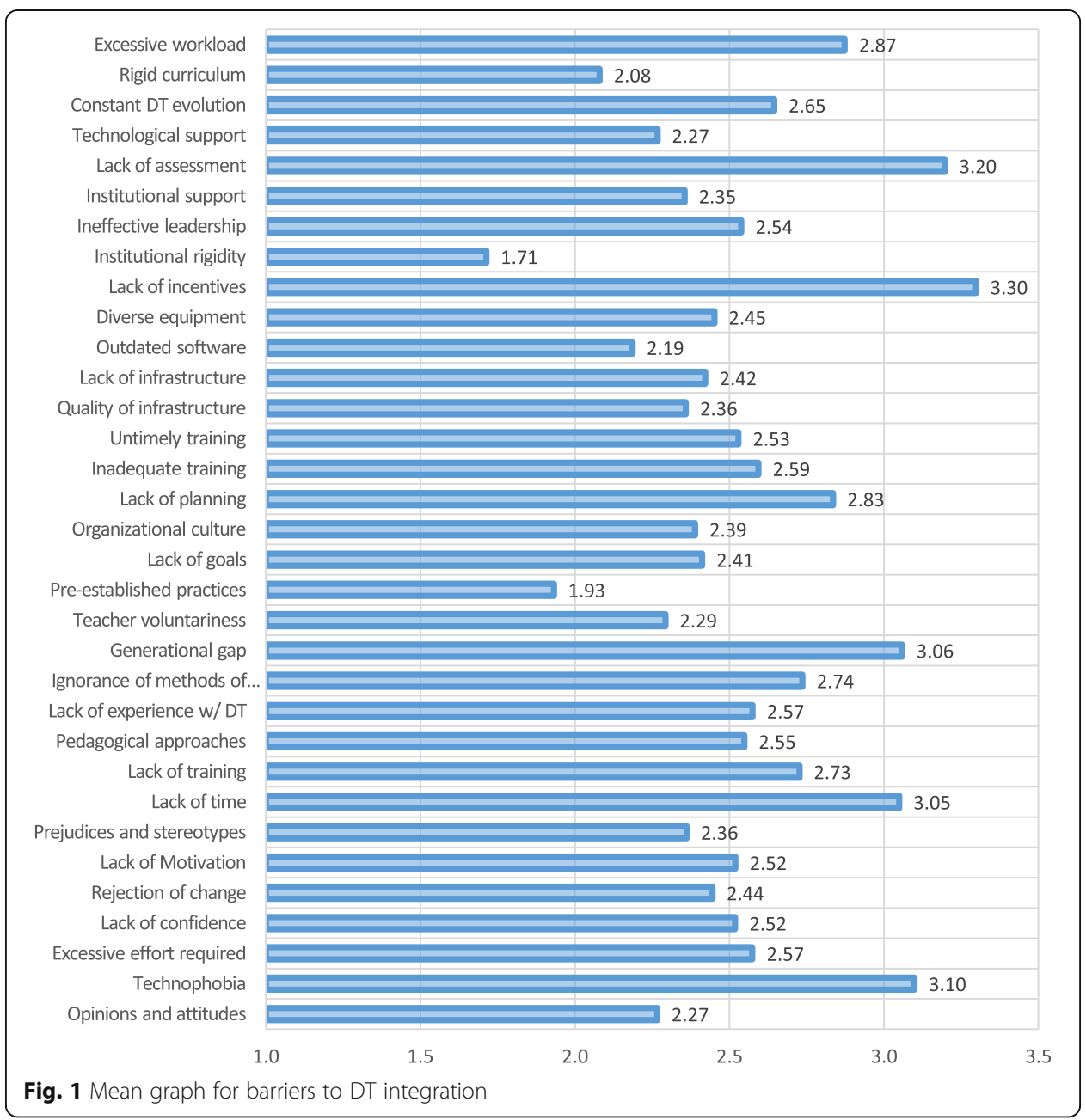

The rankings formulated by calculating the means are very similar, with results between 2.50 and 2.61. Applying the Wilcoxon test, professional barriers are those that differ from the rest due to the fact that they obtain a significantly higher value in every case (ZPr-Pe $=-4.541, p<0.000$; $\mathrm{ZPr}-\mathrm{I}=-6.764, p<0.000$; $\mathrm{ZPr}-\mathrm{C}=-3.103, p<0.002$ ); the rest of the comparisons of means, however, are not significant $(\mathrm{Z}$ Pe- $\mathrm{I}=-1.902$, $p<0.057 ; \mathrm{Z} \mathrm{Pe}-\mathrm{C}=-0.158, p<0.874 ; \mathrm{Z}$ C-I $=-1.197, p<0.231$ ).

\section{Differences according to academic discipline}

In relation to academic disciplines -using the quartile of the highest mean rankings $(M>2.73)$ as a reference- we see similar results across different fields (Figs. 2, 3, 4 and 5). Arts and humanities teachers identified nine main barriers to integrating digital

Table 2 Mean ranking for barriers to DT integration according to dimension

\begin{tabular}{lllll}
\hline & Personal $(\mathrm{Pe})$ & Professional $(\mathrm{Pr})$ & Institutional (I) & Contextual (C) \\
\hline Mean & 2.5411 & 2.6150 & 2.5031 & 2.5326 \\
$\mathrm{~N}$ & 527 & 527 & 527 & 527 \\
Standard deviation & .40560 & .39423 & .48124 & .52739 \\
\hline
\end{tabular}


Arts and Humanities $\quad$ Social Sciences $\quad$ Health Sciences $\quad$ Science and technology $\longrightarrow$ Mean

3.5
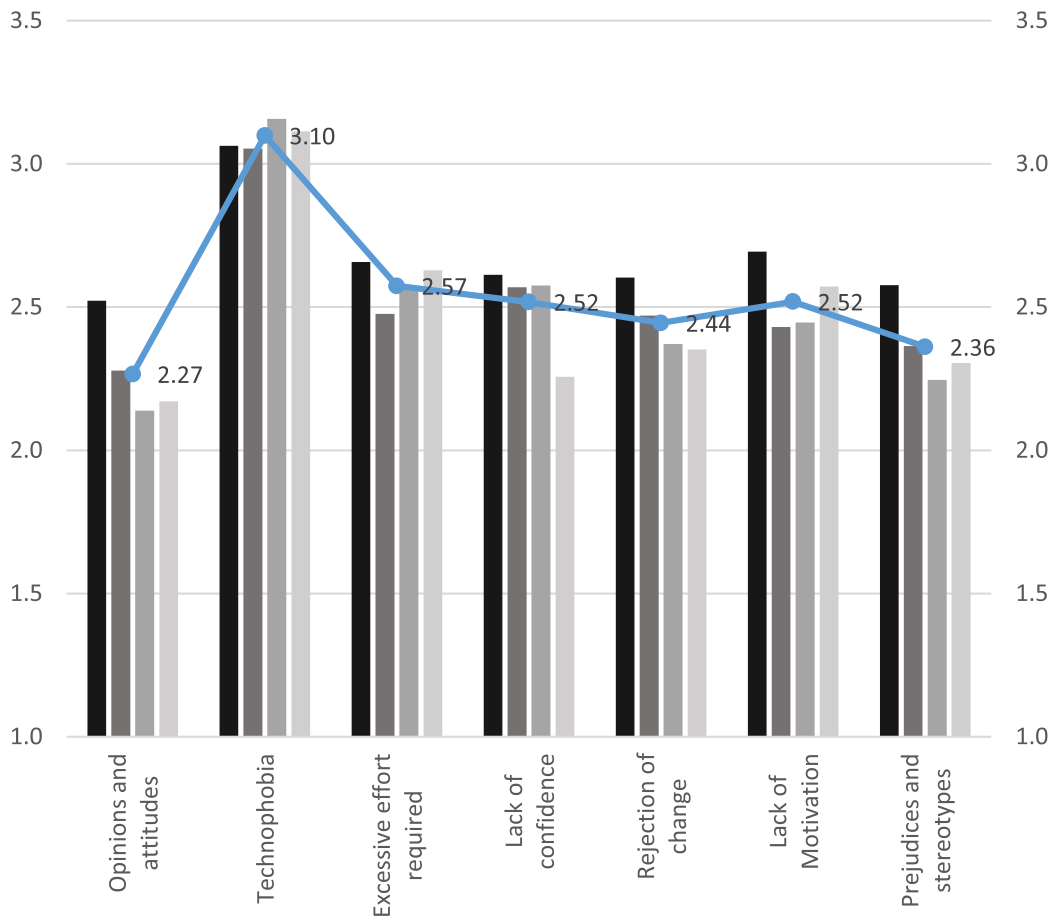

Fig. 2 Mean ranking for personal barriers to DT integration according to academic discipline

Arts and Humanities $\square$ Social Sciences Health Sciences Science and technology $\longrightarrow$ Mean 3.5

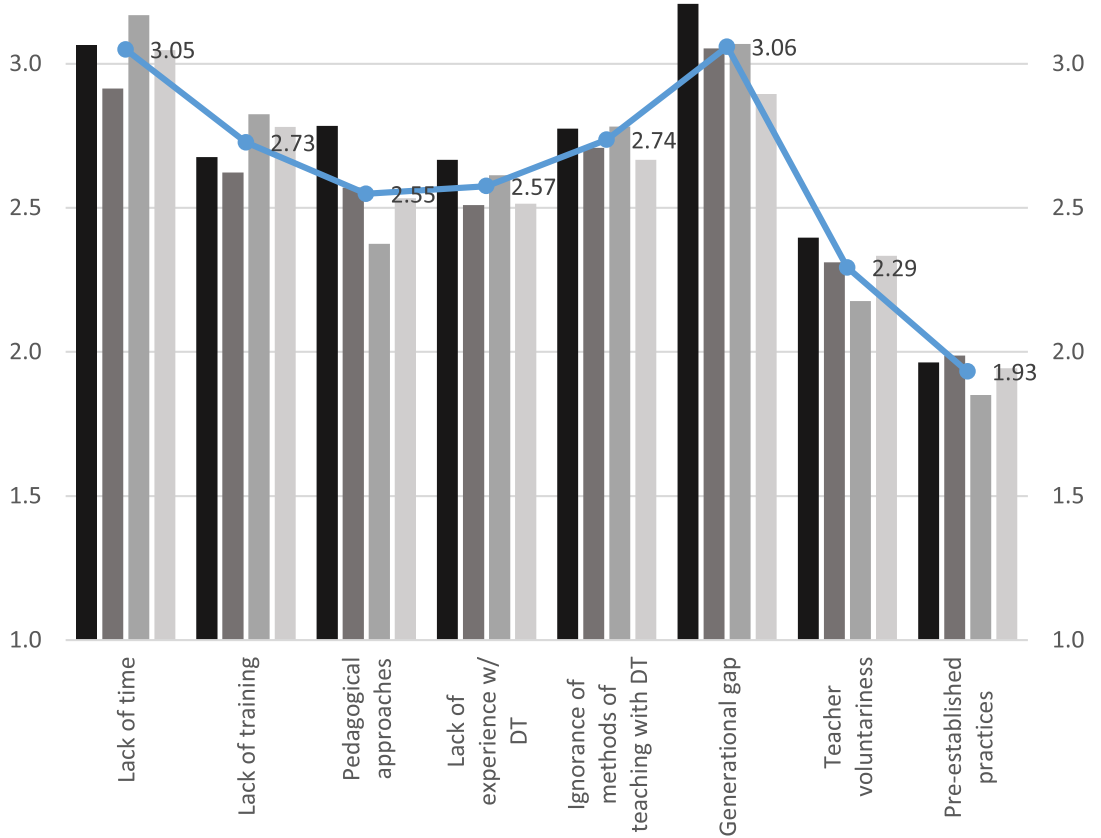

Fig. 3 Mean ranking for professional barriers to DT integration according to academic discipline 


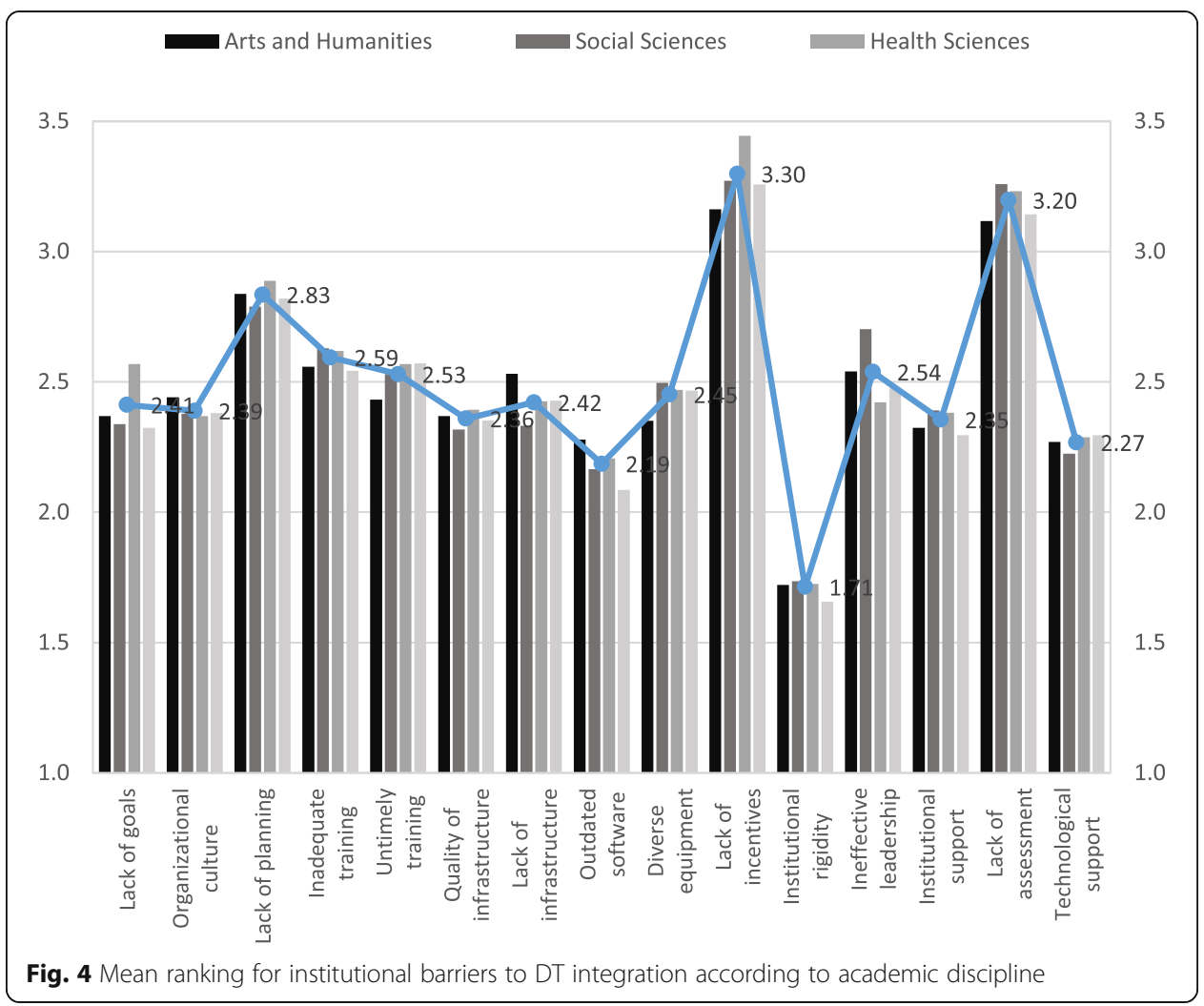

technologies: personal barriers (Fig. 2) such as technophobia $(\mathrm{M}=3.06, \mathrm{SD}=0.81)$; professional barriers (Fig. 3), such as the lack of time $(\mathrm{M}=3.06, \mathrm{SD}=0.79)$, pedagogical approaches $(\mathrm{M}=2.78, \mathrm{SD}=0.64)$, and lack of knowledge of DT teaching approaches $(\mathrm{M}=$ 2.77, $\mathrm{SD}=0.68)$; institutional barriers (Fig. 4), such as lack of incentives $(\mathrm{M}=3.16, \mathrm{SD}=$ $0.72)$, lack of assessment $(\mathrm{M}=3.12, \mathrm{SD}=0.89)$, and lack of planning $(\mathrm{M}=2.84, \mathrm{SD}=0.94)$; and contextual barriers (Fig. 5), such as the generational gap $(\mathrm{M}=3.21, \mathrm{SD}=0.79)$ and excessive workload $(\mathrm{M}=2.95, \mathrm{SD}=0.87)$.

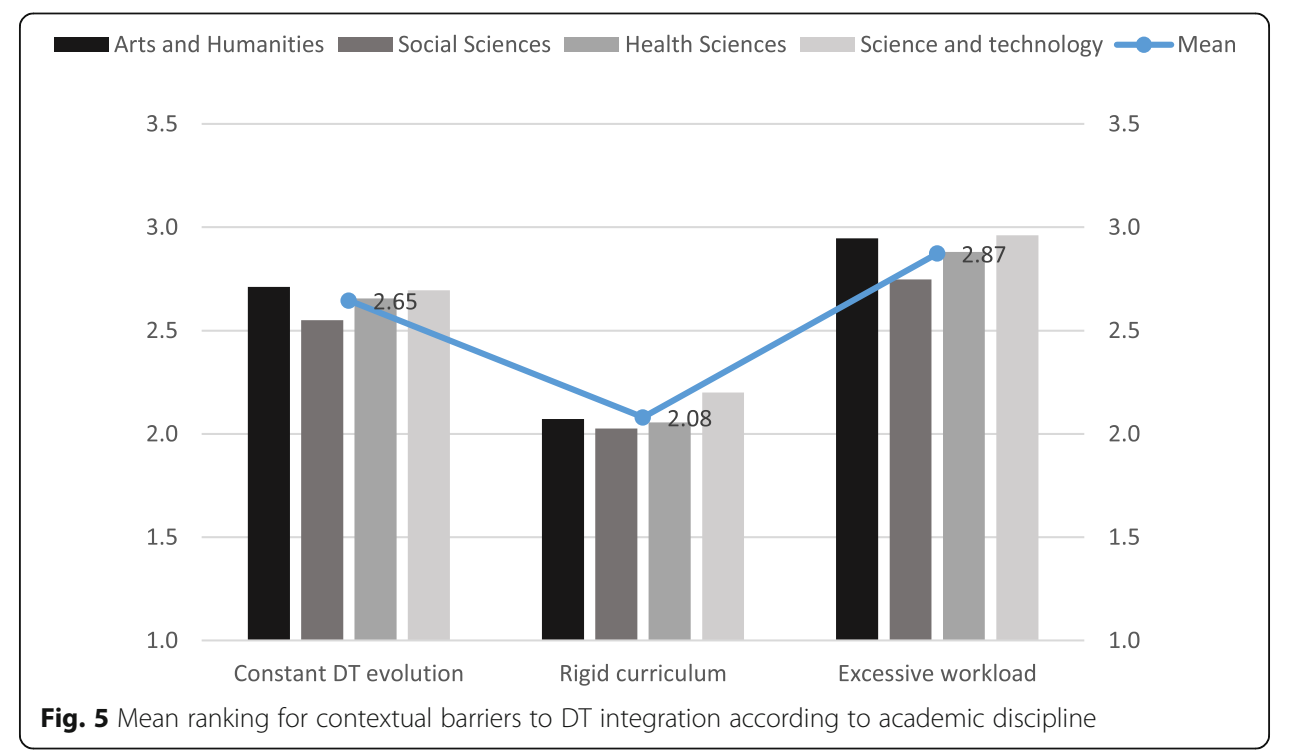


Teachers in the social sciences identified seven main barriers: one personal barrier (Fig. 2): technophobia $(\mathrm{M}=3.05, \mathrm{SD}=0.81)$; one professional barrier (Fig. 3): lack of time $(\mathrm{M}=2.91, \mathrm{SD}=0.82)$; three institutional barriers (Fig. 4): lack of incentives $(\mathrm{M}=$ $3.27, \mathrm{SD}=0.70)$, lack of assessment $(\mathrm{M}=3.26, \mathrm{SD}=0.78)$, and lack of planning $(\mathrm{M}=$ $2.79, \mathrm{SD}=0.81)$; and two contextual barriers (Fig. 5): the generational gap $(\mathrm{M}=3.05$, $\mathrm{SD}=0.81)$ and excessive workload $(\mathrm{M}=2.75, \mathrm{SD}=0.86)$.

For teaching staff in the health sciences, there were nine barriers: one personal barrier (Fig. 2): technophobia $(\mathrm{M}=3.16, \mathrm{SD}=0.79)$; three professional barriers (Fig. 3): lack of time $(\mathrm{M}=3.17, \mathrm{SD}=0.74)$, lack of knowledge of DT teaching approaches $(\mathrm{M}=2.78$, $\mathrm{SD}=0.63)$, and lack of training $(\mathrm{M}=2.83, \mathrm{SD}=0.81)$; three institutional barriers (Fig. 4): lack of incentives $(\mathrm{M}=3.44, \mathrm{SD}=0.72)$, lack of assessment $(\mathrm{M}=3.23, \mathrm{SD}=0.82)$, and lack of planning $(\mathrm{M}=2.89, \mathrm{SD}=0.85)$; and two contextual barriers (Fig. 5): the generational gap $(\mathrm{M}=3.07, \mathrm{SD}=0.86)$ and excessive workload $(\mathrm{M}=2.88, \mathrm{SD}=0.87)$.

Lastly, and in the case of science and technology teachers, the following eight barriers were identified: one personal barrier (Fig. 2): technophobia $(\mathrm{M}=3.11, \mathrm{SD}=0.85)$; two professional barriers (Fig. 3): lack of time $(\mathrm{M}=3.05, \mathrm{DT}=0.79)$ and lack of training $(\mathrm{M}=2.78, \mathrm{SD}=0.71)$; three institutional barriers (Fig. 4): lack of incentives $(\mathrm{M}=3.26$, $\mathrm{SD}=0.78)$, lack of assessment $(\mathrm{M}=3.14, \mathrm{SD}=0.74)$, and lack of planning $(\mathrm{M}=2.82$, $\mathrm{SD}=0.77)$; and two contextual barriers (Fig. 5): excessive workload $(\mathrm{M}=2.96, \mathrm{SD}=$ $0.87)$, and the generational gap $(\mathrm{M}=2.78, \mathrm{SD}=0.81)$.

As demonstrated in Figs. 2, 3, and 4, the most prominent barriers detected are considerably homogeneous across academic disciplines, although some mean rankings are higher than others. Using ANOVA for comparing the means identifies some significant differences between academic disciplines: ineffective leadership $[\mathrm{F}(3,522)=3.41, p=$ 0.017 , prejudices and stereotypes [F $(3,522)=3.47, p=0.016]$, lack of motivation [F (3, $522)=4.35, p=0.005]$, opinions and attitudes $[\mathrm{F}(3,522)=5.28, p=0.001]$, teachers' voluntariness $[\mathrm{F}(3,522)=3.16, p=0.024]$, lack of confidence $[\mathrm{F}(3,523)=5.22, \mathrm{p}=0.001]$, lack of incentives $[\mathrm{F}(3,523)=3.59, p=0.014]$, lack of time $[\mathrm{F}(3,523)=2.77, p=0.041]$, rejection of change $[\mathrm{F}(3,522)=3.99, p=0.008]$ and pedagogical approaches $[\mathrm{F}(3$, 523) $=9.11, p=0.000]$.

By applying the Bonferroni correction to check between which fields these significant differences exist, we detected that, in general, the arts and humanities obtained significantly higher mean rankings and, therefore, have more identified barriers. The arts and humanities obtained higher values than health sciences regarding the barrier of prejudices and stereotypes $(p=0.011)$. Lack of motivation is significantly more recurrent among arts and humanities teachers than in the social sciences $(p=0.009)$ and the health sciences $(p=0.016)$. Likewise, teachers of the arts and humanities believe that there are opinions and attitudes that represent a significantly greater barrier than in health sciences $(\mathrm{p}=0.001)$ and in science and technology $(p=0.012)$.

Regarding the generational gap, arts and humanities teachers identified this barrier more than science and technology teachers $(p=0.033)$; the same occurred with the lack of voluntariness of arts and humanities teachers compared to that of health sciences teachers $(p=0.024)$ and also in the rejection of change, where arts and humanities obtained a significantly higher average than health sciences $(\mathrm{p}=0.016)$ and science and technology $(p=0.019)$. The most flagrant case was that of pedagogical approaches, where the arts and humanities mean ranking was significantly higher than that of the 
social sciences $(p=0.044)$, health sciences $(p=0.000)$, and science and technology $(\mathrm{p}=$ 0.024). The opposite occurred with lack of incentives, which health sciences teachers identified as a barrier more than arts and humanities teachers did $(p=0.011)$.

There were also significant differences between the social sciences and the health sciences in terms of the ineffective leadership barrier: the former obtained higher values in ineffective leadership $(p=0.014)$, as well as in lack of time, which was identified more by health sciences teachers $(p=0.025)$ than by those of social sciences. For lack of confidence, there were differences between the arts and humanities $(p=0.004)$, the social sciences $(p=0.008)$, and the health sciences $(p=0.006)$ compared to science and technology, which obtained lower mean rankings.

\section{Discussion and conclusions}

This study confirms the existence of barriers to integrating digital technology in university teaching and specifically identifies the most prevalent barriers according to the teachers' perception, thus following the line of thought proposed by BECTA (2004), Kalembera and Majawa (2015), and Peansupap and Walker (2006).

The results of the study allow us to confirm the first proposed hypothesis, which was that "there is a sphere of intervention (personal, professional, institutional, and contextual) in which barriers are detected at greater intensity." Professional barriers obtained significantly higher rankings than other types of barriers. It therefore makes sense to supplement the classification systems proposed by, among others, Buchanan et al. (2013), Magen-Nagar and Maskit (2016), and Schulz et al. (2015) by incorporating the professional sphere into the types of barriers. This nuance allows us to discern between personal and professional barriers; this has in turn allowed us to confirm that a person's personal traits are not as relevant to improving digital technology integration as are his or her professional attributes. The study allows us to conclude that one of the keys to breaking down existing barriers involves strengthening teachers' professional development in terms of digital competencies (time management, training, pedagogical approaches, experience and teaching approaches using digital technologies, etc.).

The second hypothesis of the study states that "barriers vary depending on the university teachers' academic discipline." Upon analysing the data, the null hypothesis was confirmed, asserting that the type of academic discipline is an influential factor in teachers' perception of barriers. The results coincide in part with those of Velasco (2011) in that they suggest that teachers in the arts and humanities are, significantly, the ones who perceive the most barriers to integrating digital technologies in practically every case. Occasionally, a barrier is perceived more in the rest of the academic disciplines (Shelton, 2014), although science and technology teachers' face the fewest barriers of all, which falls in line with Salcines et al. (2017). The results regarding institutional barriers do not allow for conclusions on any one discipline in which more obstacles are felt, which makes sense if we consider that institutional barriers encompass the entire organization and do not depend on a particular discipline's characteristic or on personal traits.

Of the 33 barriers proposed to university teaching staff, only two of them were not considered to be obstacles: institutional rigidity and pre-established practices. Nevertheless, all the other barriers, to a greater or lesser extent, seem to be considered by teachers. The analysis allows us to establish that, among the different barriers, teachers 
identify the following as the most predominant ones in the university context: lack of incentives, lack of assessment, technophobia, the generational gap, lack of time, excessive workload, lack of planning, lack of knowledge of digital technology teaching approaches, and lack of training. This study therefore fleshes out the theoretical review by uncovering the specific obstacles that teachers perceive, in the different barrier areas analysed (personal, professional, institutional, and contextual), as reasons for not integrating digital technologies. The literature takes the different barrier areas into account equally, although the barrier of lack of training comes up more frequently (Chukwunonso \& Oguike, 2013; Gómez, 2017; Marín et al., 2012; Salcines et al., 2017; Zempoalteca et al., 2017). We believe that, in order to address the most prevailing barriers, there is a need for commitment, on the part of organizations, through the development and implementation of an institutional plan (Chukwunonso \& Oguike, 2013; Duart, 2011; El Semary, 2011; Llorens et al., 2016; Mercader, 2019) that is more strategic than operational (Valverde et al., 2010), as well as the involvement of the teaching staff.

A correct interpretation of the results must also consider the limitations of the study. On the one hand, the research was carried out within a specific context, which means we should be cautious about generalizing by applying the data to other contexts. On the other hand, the data obtained in this study was collected using a closed questionnaire, which may have limited the emergence of other barriers not previously identified in the literature. For this reason, for future research we recommend collecting qualitative data to confirm and expand on teachers' perceptions. Future lines of research could elaborate on the results through qualitative data and could compare the real use of the tools with the perception of barriers, as well as the influence of other factors such as age and gender. Regarding disciplines and digital technology, further research could analyse clusters and create profiles of teachers depending on the perception of barriers and their disciplines.

\section{Acknowledgements}

Not applicable.

\section{Authors' contributions}

CM gather, analysed and interpret the data gathered. JG established the theoretical framework, adviced on methodology, and together with CM draw conclusions and discussion. Both authors read and approved the final manuscript.

Funding

This work was supported by the University Teacher Training Program (FPU), Ministry of Education, Sports and Culture of Spain, under Grant FPU/2650.

Availability of data and materials

The datasets used and/or analysed during the current study are available from the corresponding author on reasonable request.

Competing interests

The authors declare that they have no competing interests.

Received: 13 November 2019 Accepted: 4 February 2020

Published online: 09 March 2020

References

Al-Senaidi, S., Lin, L., \& Poirot, J. (2009). Barriers to adopting technology for teaching and learning in Oman. Computers \& Education, 53, 579-590. https://doi.org/10.1016/j.compedu.2009.03.015.

BECTA [British Educational Communications and Technology Agency] (2004). A review of the research literature on barriers to the uptake of ICT by teachers. Report Retrieved from http://dera.ioe.ac.uk/1603/1/becta_2004_barrierstouptake_litrev.pdf Berzosa, I., \& Arroyo, M. J. (2016). Docentes y TIC: Un encuentro necesario. Contextos educativos, 19, 147-159. https://doi.org/ $10.18172 /$ con.2767. 
Bland, R. (2007). 'Celebrating success': A continuing professional development project in information and communication technology within a teacher training institution. In K. Kumpulainen (Ed.), Educational technology: Opportunities and challenges, (pp. 64-85). Oulu: Oulu University Press ISBN: 978-951-42-8406-9.

Buchanan, T., Sainter, P., \& Saunders, G. (2013). Factors affecting faculty use of learning technologies: Implications for models of technology adoption. Journal Computer Higher Education, 25, 1-11. https://doi.org/10.1007/s12528-013-9066-6.

Burkhardt, M. E. (1994). Social interaction effects following a technological change: A longitudinal investigation. Academy of Management Journal, 34(4), 869-898. https://doi.org/10.5465/256603.

Cabero, J. (2005). Las TICs y las Universidades: retos, posibilidades y preocupaciones. Revista de la educación superior, 34(3), 77-100.

Chukwunonso, F., \& Oguike, M. C. (2013). An evaluation framework for new ICTs adoption in architectural education. International Journal of Informatics and Communication Technology (IJ-ICT), 2(3), 183-189. https://doi.org/10.11591/ij-ict.v2i3.5285.

Cuhadar, C. (2018). Investigation of pre-service teachers' levels of readiness to technology integration in education. Contemporary Educational Technology, 9(1), 61-75

Duart, J. M. (2011). La Red en los procesos de enseñanza de la Universidad. Comunicar, 37(19), 10-13. https://doi.org/10.3916/ C37-2011-02-00

El Semary, H. (2011). Barriers to the effective use of technology in education: Case study of UAE. Asian Transactions on Science \& Technology, 1(5), 22-32.

Ertmer, P. A. (1999). Addressing first- and second-order barriers to change: Strategies for technology integration. Educational Technology Research \& Development, 47(4), 47-61. https://doi.org/10.1007/BF02299597.

Gómez, J. (Ed.) (2017). UNIVERSITIC 2017. Análisis de las TIC en las Universidades Españolas. Madrid: CRUE Universidades Españolas ISBN: 978-84-697-9759-4.

Gumbau, J. P., Llorens, F., Molina, R., Canay, J. R., Fernández, S., Rodeiro, D., ... Zapata-Ros, M. (2016). Más allá de los datos. In J. Gómez (Ed.), UNIVERSITIC 2016. Análisis de las TIC en las Universidades Españolas, (pp. 106-143). Madrid: Crue Universidades Españolas ISBN: 978-84-617-5525-7.

Hernández-Ramos, J. P., Martínez-Abad, F., García, F. J., Herrera, M. E., \& Rodríguez-Conde, M. J. (2014). Teachers' attitude regarding the use of ICT. A factor reliability and validity study. Computers in Human Behavior, 31, 509-516. https://doi.org/ 10.1016/j.chb.2013.04.039.

Hue, L. T., \& Jalil, H. A. (2013). Attitudes towards ICT integration into curriculum and usage among university lecturers in Vietnam. International Journal of Instruction, 6(2), 53-66 ISSN: 1308-1470.

Johnson, L., Adams Becker, S., Cummins, M., Estrada, V., Freeman, A., \& Hall, C. (2016). NMC horizon report: 2016 higher education edition. Resource document. Austin: The New Media Consortium https://www.sconul.ac.uk/sites/default/files/ documents/2016-nmc-horizon-report-he-EN-1.pdf. Accessed 10 Oct 2019.

Kalembera, L., \& Majawa, F. (2015). The integration of ICTs into the learning activities of the College of Medicine undergraduate students. In IST-Africa 2015 conference proceedings, (pp. 1-10). Lilongwe: Institute of Electrical and Electronics Engineers (IEEE). ISBN. 978-1-905824-51-9.

Kedrova, G., \& Potemkin, S. (2015). New trends in implementation of ICT in higher education. In 9th international conference on Application of Information and Communication Technologies (AICT), (pp. 1-5) https://ieeexplore.ieee.org/stamp/stamp. jsp?tp=\&arnumber=7338617. Accessed 9 Oct 2019.

Kurt, S. (2011). How do teachers prioritize the adoption of technology in the classroom? Teachers and Teaching, 18(2), 217231. https://doi.org/10.1080/13540602.2012.632271

Lincoln, Y. S., \& Guba, E. G. (1985). Naturalistic inquiry. Londres: SAGE Publications ISBN: 0-8039-2431-3.

Llorens, F., Fernández, A., Canay, J. R., Fernández, S., Rodeiro, D., Ruzo, E., \& Sampalo, F. J. (2016). Gestión de las TI. In J. Gómez (Ed.), UNIVERSITIC 2016. Análisis de las TIC en las Universidades Españolas, (pp. 21-56). Madrid: Crue Universidades Española.

Magen-Nagar, N., \& Maskit, D. (2016). Integrating ICT in teacher colleges - a change process. Journal of Information Technology Education: Research, 15, 211-232. https://doi.org/10.28945/3512

Marcelo, C., Yot, C., \& Mayor, C. (2015). Enseñar con tecnologías digitales en la Universidad. Comunicar, 45(23), $117-124$. https://doi.org/10.3916/C45-2015-12.

Marín, V., Vázquez, A. I., Llorente, M. C., \& Cabero, J. (2012). La Alfabetización Digital del docente universitario en el Espacio Europeo de Educación Superior. EDUTEC. Revista Electrónica de Tecnología Educativa, 39, 1-10. https://doi.org/10.21556/ edutec.2012.39.377

Mercader, C. (2019). Las resistencias del profesorado universitario a la utilización de las tecnologías digitales. Aula Abierta, 48(2), 167-174. https://doi.org/10.17811/rifie.48.2.2019.167-174.

Mercader, C., \& Gairín, J. (2017). ¿Cómo utiliza el profesorado universitario las tecnologías digitales en sus aulas? Revista de Docencia Universitaria (REDU), 15(2), 257-274. https://doi.org/10.4995/redu.2017.7635.

Pajo, K., \& Wallace, C. (2001). Barriers to the uptake of web-based technology by university teachers. International Journal of ELearning \& Distance Education, 16(1), 70-84.

Peansupap, V., \& Walker, D. H. T. (2006). Information communication technology (ICT) implementation constraints. Engineering, Construction and Architectural Management, 13(4), 364-379. https://doi.org/10.1108/09699980610680171.

Prendes, M. P. (2010). Competencias TIC para la docencia en la Universidad pública española: indicadores y propuestas para la definición de buenas prácticas. Informe del Proyecto EA-2009-0133 de la Secretaría de Estado y Universidades e Investigación Resource document. http://www.um.es/competenciastic/informe_final_competencias2 010.pdf Accessed 11 Oct 2019.

Quicios, M. P. (2015). Los dispositivos digitales móviles en educación superior: usos y experiencias. In E. E. Vázquez, \& M. L. Sevillano (Eds.), Dispositivos digitales móviles en educación. El aprendizaje ubicuo, (pp. 49-66). Madrid: Narcea Ediciones ISBN: 978-84-277-2100-5.

Robbins, S. P., \& Judge, T. A. (2013). Organizational behaviour, (15th ed., ). New Jersey: Pearson Education Inc ISBN: 978-0-13283487-2.

Romero, M. (2011). Disseny i avaluació d'un Centre Virtual de Recursos de Tecnologia Educativa com a eina de formació dels mestres en l'ús de les TIC (Doctoral dissertation). https://www.tdx.cat/handle/10803/42930. Accessed 10 Oct 2019

Salcines, l., González, N., \& Briones, E. (2017). Perfiles docentes universitarios: Conocimiento y uso profesional del smartphone. Bordón, 69(2), 91-114. https://doi.org/10.13042/Bordon.2017.51445 ISSN: 0210-5934. 
Salinas, J. (2008). Innovación educativa y uso de las TIC. Sevilla: Universidad Internacional de Andalucía ISBN: 978-847993-055-4.

Schulz, R., Isabwe, G. M., \& Reichert, F. (2015). Investigating teachers motivation to use ICT tools in higher education. In Proceedings of the 6th international conference internet technologies and applications (ITA), (pp. 62-67) ISBN: 978-1-4799-8036-9.

Selwyn, N. (2007). The use of computer technology in university teaching and learning: To critical perspective. Journal of Computer Assisted Learning, 23, 83-94. https://doi.org/10.1111/j.1365-2729.2006.00204.x.

Sevillano, M. L. (2015). El contexto socioeducativo de la ubicuidad y la movilidad. In E. Vázquez, \& M. Sevillano (Eds.) Dispositivos digitales móviles en educación. El aprendizaje ubicuo, (pp. 17-38). Madrid: Narcea Ediciones ISBN: 97884-277-2100-5.

Shelton, C. (2014). "Virtually mandatory": A survey of how discipline and institutional commitment shape university lecturers 'perceptions of technology. British Journal of Educational Technology, 45, 748-759. https://doi.org/10.1111/bjet.12051.

Tejada, J. (1998). Los agentes de innovación en los centros educativos: profesores, directivos y asesores. Málaga: Aljibe.

Teo, T. (2015). Comparing pre-service and in-service teachers' acceptance of technology: Assessment of measurement invariance and latent mean differences. Computers \& Education, 82, 22-31. https://doi.org/10.1016/j.compedu.2014.11.015.

Valverde, J., Garrido, M. C., \& Sosa, M. J. (2010). Políticas educativas para la integración de las TIC en Extremadura y sus efectos sobre la innovación didáctica y el proceso enseñanza-aprendizaje: la percepción del profesorado. Revista de Educación, $352,99-124$.

Vázquez, E. (2015). Aprendizaje ubicuo y móvil mediante "apps". In E. Vázquez, \& M. L. Sevillano (Eds.), Dispositivos digitales móviles en educación. El aprendizaje ubicuo, (pp. 135-154). Madrid: Narcea Ediciones ISBN: 978-84-277-2100-5.

Velasco, L. (2011). TIC en las aulas: La Universidad de Santiago de Compostela. In J. Hernández Ortega, M. Pennesi Fruscio, D. Sobrino López, \& A. Vázquez Gutiérrez (Eds.), Experiencias educativas en las aulas del siglo XXI. Innovación con TIC. Barcelona: Ariel ISBN: 978-84-08-10551-0.

Venkatesh, V. (2000). A theoretical extension of the technology acceptance model: Four longitudinal field studies. Management Science, 46(2), 186-204. https://doi.org/10.1287/mnsc.46.2.186.11926.

Yin, R. K. (1994). Case study research: Design and methods, (8th edición ed., ). Newbury Park: SAGE Publications.

Zempoalteca, B., Barragán, J. F., González, J., \& Guzmán, T. (2017). Formación en TIC y competencia digital en la docencia en instituciones públicas de educación superior. Apertura, 9(1), 80-96. https://doi.org/10.32870/Ap.v9n1.922.

\section{Publisher's Note}

Springer Nature remains neutral with regard to jurisdictional claims in published maps and institutional affiliations.

\section{Submit your manuscript to a SpringerOpen ${ }^{\circ}$ journal and benefit from}

- Convenient online submission

- Rigorous peer review

- Open access: articles freely available online

High visibility within the field

Retaining the copyright to your article

Submit your next manuscript at $\boldsymbol{\sim}$ springeropen.com 